\title{
Uric Acid Metabolism in Therapy of Glycogen Storage Disease Type I
}

\author{
PAUL J. BENKE ${ }^{(31)}$ AND SCOTT GOLD \\ The Mailman Center and the Department of Pediatrics, University of Miami School of Medicine, Miami, Florida, \\ USA
}

\section{Summary}

Factors which may explain lower serum uric acid in a new therapy of patients with glycogen storage disease (GSD) type I have been studied. $\left[1{ }^{14} \mathrm{C}\right]$ Glycine incorporation into urine uric acid was $0.68 \%$ of the injected dose during a 6 -day period of frequent high carbohydrate feedings, $0.40 \%$ with the same diet and nocturnal nasogastric feeding by Vivonex, and $0.18 \%$ in a control patient with GSD type III. Fractional renal uric acid excretion in the patient with GSD type $I$ increased from $11.3 \%$ to $26.3 \%$ after beginning nocturnal nasogastric feeding of Vivonex. Red cell phosphoribosylpyrophosphate levels were not changed by the therapy. Addition of Vivonex nocturnal feedings to frequent high carbohydrate feedings (1) decreased the accelerated de novo purine synthesis to a level still higher than control and (2) increased fractional renal uric acid excretion.

\section{Speculation}

Near normalization of purine metabolism with nocturnal feeding should decrease the risk of gout in GSD type I.

Patients with GSD type I (Von Gierke's disease, glucose-6phosphatase deficiency) have hypoglycemia, metabolic acidosis, elevated serum lactic acid, hyperlipemia, hypophosphatemia, hyperuricemia and hepatomegaly, and severe growth failure. Elevated serum uric acid often leads to gout and uric acid nephropathy in affected teenagers and young adults $(4,11,12$, 22). Several mechanisms combine to raise serum uric acid. A high serum lactic acid reduces renal uric acid excretion $(4,13$, $24)$. Elevated serum ketone concentrations potentially decrease renal uric acid excretion (6). Patients have an acceleration of de novo synthesis of uric acid from precursors $(12,14,15)$. Uric acid binding to increased levels of lipoproteins may be a factor, and excessive breakdown of cellular purines to uric acid has been proposed (8). The relative contribution of these elements to increased serum uric acid levels and total uric acid pool size in patients has not been determined.

Burr et al. (1) have demonstrated that continuous 24-hr intragastric feeding is effective in modifying the metabolic abnormalities seen in GSD type I. However, continuous feedings by stomach tube is impractical. Green et al. (7) found that infusion of a high glucose formula did not have to be continuous, for the metabolism of these patients also significantly improves when feeding at night by nasogastric tube is added to frequent daytime feeding. Serum uric acid was reduced to normal in two of the three patients studied (7). We report here studies of the mechanism of this decrease.

\section{MATERIALS AND METHODS}

Uric and lactic acids were determined by enzymatic assay with uricase (18) and lactic acid dehydrogenase (21). $\left[1{ }^{-14} \mathrm{C}\right]$ Glycine was obtained from New England Nuclear Corporation (Boston,
MA). Red cell phosphoribosylpyrophosphate (PRPP) levels were determined in a rate-limiting reaction with partially purified hypoxanthine-guanine phosphoribosyltransferase (10).

An 8-year-old patient with the signs of symptoms of GSD type I and almost complete absence of liver glucose-6-phosphatase activity was studied. A patient with GSD type III with absent debrancher enzyme (26) was a control. Informed consent was obtained and the study approved by the Committee for Protection of Human Subjects, University of Miami Medical School.

A high carbohydrate diet consisting of 1500 calories and low in purines was started 1 week before glycine radiochemical injection and continued for the duration of the study. The patient was fed hourly during the day. In a control study, $2 \mu \mathrm{Ci} /$ $\mathrm{kg}\left[1-{ }^{14} \mathrm{C}\right]$ glycine was injected iv and $\left[{ }^{14} \mathrm{C}\right]$ uric acid was isolated from the urine by repeated precipitation after addition of nonisotopic carrier (22). Isolated uric acid was solubilized in Hyamine, added to Scintisol, and radioactivity determined in a Packard liquid scintillation counter. Renal uric acid excretion was determined in the morning during a 3-hr fast (17). The experimental period consisted of the same diet, except that onethird of the total calories were administered over $10 \mathrm{hr}$ at night by nasogastric feeding of Vivonex (7). Renal uric acid excretion was restudied 3 days after adding Vivonex nocturnal feeding by nasogastric tube to the same diet. A second $\left[1-{ }^{14} \mathrm{C}\right]$ glycine incorporation into uric acid was done 1 month after the first radiochemical study and 5 days after institution of nasogastric Vivonex.

\section{RESULTS}

In the 6 months since nocturnal feeding began, growth rate in the patient with GSD type I increased 5-fold. Eleven hours after the first nocturnal feeding, uric acid decreased from 10.1 to 4.8 $\mathrm{mg} / 100 \mathrm{ml}$. It can be seen in Table 1 that red cell PRPP concentration did not change with the addition of nocturnal feeding. Nocturnal feeding by nasogastric tube increased renal uric acid excretion from $11.3 \%$ to $26.3 \%$ as shown in Table 1 . Blood measurements could not be collected in this patient at night during the first times on the nocturnal feedings, to determine whether uric acid excretion improved before lactic acid levels were lowered. Specific activity of urine uric acid and 6 -day incorporation of $\left[1-{ }^{14} \mathrm{C}\right]$ glycine into $\left[{ }^{14} \mathrm{C}\right]$ uric acid decreased when nocturnal feeding by nasogastric feeding was begun, as shown in Figure 1 and Table 1, but remained greater than control. The patient with GSD type III had a $\left[1-{ }^{14} \mathrm{C}\right]$ glycine uptake into uric acid similar to that of previous control subjects $(14,15)$.

\section{DISCUSSION}

An unexpected part of this study was the manner in which television viewing was an influence. Two patients with GSD type I watch a program called "Welcome Back Kotter" where 
Table 1. Uric acid metabolism during frequent high carbohydrate feeding (period I) and frequent high carbohydrate feeding and nocturnal infusion of Vivonex (period II) ${ }^{1}$

\begin{tabular}{|c|c|c|c|}
\hline & Control & Period I & Period II \\
\hline Serum uric acid $(\mathrm{mg} / 100 \mathrm{cc})$ & $3-7$ & 9.9 & 4.6 \\
\hline Serum fasting lactic acid $(\mathrm{mg} / 100$ & $15^{2}$ & 97.0 & 55.8 \\
\hline cc) $($ after $3 \mathrm{hr})$ & & & - \\
\hline Serum glucose $(\mathrm{mg} / 100 \mathrm{cc})$ & & 20 & 90 \\
\hline $\begin{array}{l}\text { Fractional renal excretion of uric } \\
\text { acid }(\%)\end{array}$ & & 11.3 & $26.3^{3}$ \\
\hline Red cell PRPP concentration & $8.4 \pm 4.2$ & 6.7 & 8.0 \\
\hline $\begin{array}{l}\text { (nmol PRPP/mg protein (mean } \\
\pm \mathrm{SD} \text { ) }\end{array}$ & & 6.2 & 10.3 \\
\hline $\begin{array}{l}\text { Sp act of uric acid } 24 \mathrm{hr} \text { after [1- } \\
{ }^{14} \mathrm{C} \text { ]glycine injection }(\mathrm{cpm} / \mathrm{mg})\end{array}$ & $60^{2}$ & 170 & 98 \\
\hline $\begin{array}{l}\text { Total }\left[1{ }^{-14} \mathrm{C}\right] \text { glycine incorporation } \\
\text { into uric acid ( } \% \text { of injected } \\
\text { dose) }\end{array}$ & $0.18^{2}$ & 0.68 & 0.40 \\
\hline Growth rate per month $(\mathrm{cm})$ & & 0.20 & 1.0 \\
\hline
\end{tabular}

${ }^{1}$ Blood studies were done on early morning samples.

2 Patient with GSD type III.

${ }^{3}$ Three days after institution of nocturnal infusion.

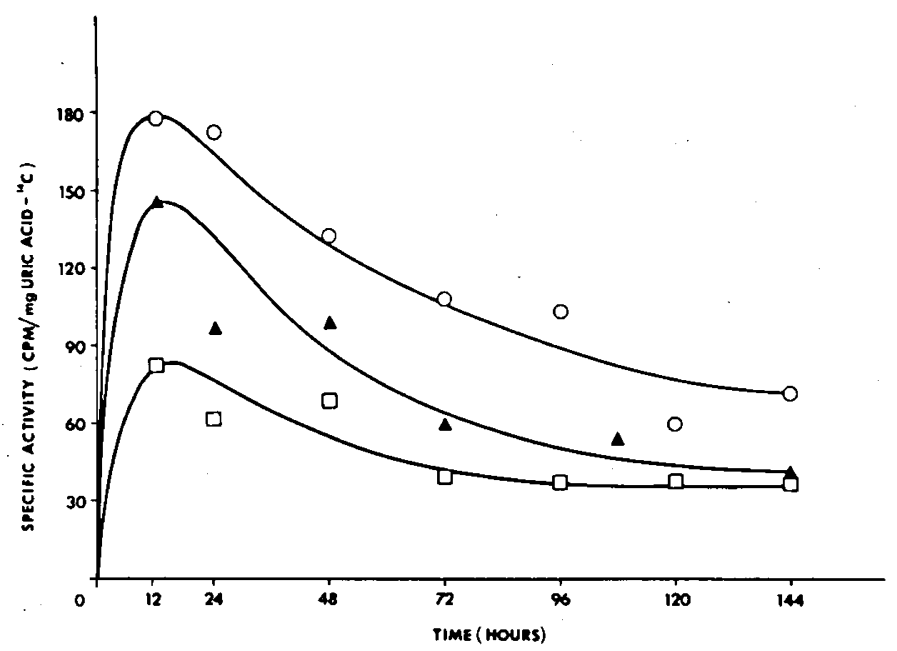

Fig. 1. Incorporation of $2 \mu \mathrm{C} / \mathrm{kg}\left[11^{-14} \mathrm{C}\right]$ glycine into urine uric acid. Radioactive glycine was injected intravenously in a patient with GSD type I during a period of frequent daytime feeding of a high carbohydrate diet $(\mathrm{O}-\mathrm{O})$, during a period of the same diet and nocturnal nasogastric feeding of Vivonex $(\boldsymbol{\Delta}-\mathbf{\Delta})$, and in a patient with GSD type III $(\square-\square)$.

an expression used is "up your nose with a rubber hose." This was their basis for refusing the nasogastric tube and the research. A third patient accepted because he regularly viewed "The Six Million Dollar Man," and saw that Steve Austin needed a nasogastric tube during surgery for new bionic parts. After 3 days, this 8 -year-old boy could pass his own nasogastric tube at night.

The data from the patient studied suggest that changes in both de novo purine synthesis and uric acid excretion take place. Most of the metabolic alterations in GSD type I can be attributed to low blood sugar and high glucagon hormone levels, which are improved by the nocturnal nasogastric feedings (7). Hyperuricemia, however, may not be related to low blood sugar unless excessive glucagon secretion affects purine synthesis. Twenty-four hours after injection of $2 \mu \mathrm{Ci} / \mathrm{kg}\left[1-{ }^{14} \mathrm{C}\right]$ glycine, the specific activity of uric acid was three times that of a control patient. Addition of nocturnal infusion to frequent day time feeding lowered the $\left[1-{ }^{14} \mathrm{C}\right]$ glycine incorporation as shown in Table 1 and Figure 1. It is likely that the observed lowering of total de novo synthesis of uric acid by $41 \%$ in 6 days is significant. Single measurements of total synthesis under different conditions with the patient as his own control are presented. However, a wide range of accelerated total de novo purine synthesis may exist in different affected patients in the same family (12).

Phosphoribosylpyrophosphate (PRPP) and glutamine, two precursors of purine compounds, are thought to be elevated in GSD type $I$ and related to increased synthesis of uric acid (7, 12). PRPP, in particular, might be elevated since it would be expected that excess hepatic glucose-6-phosphate levels leads to excess 6-phosphogluconate and ribose-5-phosphate, the immediate precursors of PRPP. Glucose is an absolute requirement for PRPP production in vitro (10). Glucose-6-phosphate is formed both during breakdown of hepatic glycogen and by gluconeogenesis, and affected patients cannot release hepatic glucose from glucose-6-phosphate for utilization by peripheral tissues. The pathway of oxidative glucose-6-phosphate metabolism has been demonstrated in the liver of patients with GSD type I (13). However, it has not been shown that PRPP levels are increased in the liver in GSD type I patients; only red cell and fibroblast levels have been examined $(9,23)$. Normal red cell PRPP levels are found in our patient, and are not lowered with nocturnal feeding as shown in Table 1 . This may have no bearing on the pathogenesis of hyperuricemia, since red cells do not have glucose-6-phosphatase activity and the liver is the major organ for purine synthesis and glycogen metabolism in man. Keeping serum glucose levels at near normal values in affected patients by frequent feedings and nocturnal infusion of Vivonex might lessen the physiologic need by the enzymedeficient liver to increase glucose-6-phosphate production by greater glycogen breakdown and excessive gluconeogenesis.

Diet, cellular carbohydrates and uric acid metabolism relationships may be even more complex. Administration of a high carbohydrate diet increases uric acid excretion in normal subjects $(2,20)$. This may not be a factor in our studies, since the diet, high in carbohydrate, with frequent daily feedings, was not changed, but became more evenly distributed over a 24-hr period when nocturnal feedings were instituted. Additional studies would be required to determine whether uric acid metabolism is in equilibrium in GSD type I patients 5 days after a change such as the addition of nocturnal feedings. Examination of de novo purine synthesis and PRPP levels in liver parenchymal or epithelial cells may be useful in examining these questions. Epithelial cells and not fibroblasts have inducible glucose6-phosphatase activity in tissue culture (16).

Our studies suggest that the excretion of urine uric acid increased dramatically when measured 3 days after nocturnal infusion was begun, and this was associated with lower serum lactic acid. Lactic acid ions compete with uric acid ions for excretion $(5,25)$. However, Fine et al. (4) have noted that infusion of glucose in affected patients increases renal uric acid excretion before lactic acid levels fall, perhaps by providing an energy source for kidneys deficient in glucose-6-phosphatase activity. Additional studies are required to determine whether improvement in renal excretion of uric acid or decreased uric acid synthesis plays the more important role in normalization of blood uric acid in GSD type I.

The effectiveness of nocturnal infusion of high carbohydrate feeding for GSD type I has now been established $(3 ; 7,19)$. Surgical diversion of the portal vein should probably no longer be used. The studies presented here confirm the finding that feeding a high carbohydrate diet at night by nasogastric tube lowers serum uric acid (7).

\section{CONCLUSION}

Both decreased de novo synthesis of purines and increased renal uric acid excretion were associated with a lowered serum uric acid in a patient with GSD type I begun on a program of nocturnal feeding of Vivonex by nasogastric tube. 


\section{REFERENCES AND NOTES}

1. Burr, I. M. O'Neill, J. A., Karzon, D. T., Howard, L. J., and Greene, H. L.: Comparison of the affects of total parenternal nutrition, continuous intragastric feeding, and portacaval shunt on a patient with Type I glycogen storage disease. J. Pediat., 85: 792 (1974).

2. Cathcart, E. P.: The influence of carbohydrates and fats on protein metabolism. J. Physiol. (London) 39: 311 (1909).

3. Ehrlich, R. M.: Nocturnal feeding for glycogen-storage disease. N. Engl. J. Med., 294: 1125 (1976).

4. Fine, R. N., Straus, J., and Donnell, G. N.: Hyperuricemia in glycogenstorage disease Type I. Amer. J. Dis. Childhood, 112: 572 (1966).

5. Gibson, H. V., and Doisy, E. A.: A note on the effect of some organic acids upon the uric acid excretion of man. J. Biol. Chem., 55: 605 (1923).

6. Goldfinger, S., Klinenberg, J. R., and Seegmiller, J. E.: Renal retension of uric acid induced by infusion of beta-hydroxybutryate and acetoacetate. $N$. Engl. J. Med., 294: 423 (1976).

7. Greene, H. L., Slonim, A. E., O'Neill, J. A., and Burr, I. M.: Continuous nocturnal intragastric feeding for management of type I glycogen-storage disease. N. Engl. J. Med., 294: 423 (1976).

8. Greené, H. L., Wilson, F., Hefren, P., Terry, A., Slonim, A., and Burr, I.: Hyperuricemia in glycogen storage type I. Pediat. Res., 11: 515 (1977).

9. Greene, M. L., and Seegmiller, J. E.: Elevated erythrocyte phosphoribosylpyrophosphate in X-linked uric aciduria. J. Clin. Invest., 48: 32a (1969).

10. Henderson, J. F., and Khoo, M. K. T.: Synthesis of 5-phosphoribosyl-1pyrophosphate from ribonucleosides in Ehrlich ascites tumor cells in vitro. J. Biol. Chem., 240: 2363 (1965).

11. Holling, H. E.: Gout and glycogen storage disease. Ann. Intern. Med., 58: 654 (1963).

12. Howell, R. R.: The interrelationship of glycogen storage disease and gout. Arth. Rheum., 8: 780 (1965).

13. Howell, R. R., Ashton, D. M., and Wyngaarden, J. B.: Glucose-6-phosphatase deficiency glycogen storage disease. Pediatrics, 29: 533 (1962).

14. Jakovcick, S., and Sorensen, L. B.: Studies of uric acid metabolism in glycogen storage disease associated with gouty arthritis. Arth. Rheum., 10: 129 (1967)

15. Kelley, W. N., Rosenbloom, F. M., Seegmiller, J. E., and Howell, R. R.:
Excessive production of uric acid in type I glycogen storage disease. J. Pediat., 272: 488 (1968).

16. Negishi, H., and Benke, P. J.: Epithelial cells and Von Gierke's disease. Pediat. Res. 11: 936 (1977).

17. Passwell, J. H., Modan, M., Brish, M., Orda, X., and Boichis, S.: Fractional excretion of uric acid in infancy and childhood. Arch. Dis. Childhood, 49: 878 (1974).

18. Praetorius, E.: An enzymatic method for the determination of uric acid by ultraviolet spectrophotometry. Scand. J. Clin. Lab. Invest., 1: 222 (1949).

19. Roe, T. F., and Kogut, M. D.: Chronic effects of oral glucose alimentation and portacaval shunt in patients with glycogen storage disease type $I$. Pediat. Res., 10: 414 (1976).

20. Rose, W. C.: The influence of food ingestion upon endogenous purine metabolism. J. Biol. Chem., 48: 575 (1921).

21. Sigma Chemical Technical Bulletin, St. Louis, MO.

22. Sorensen, L. B.: Suppression of the shunt pathway in primary gout with azathioprine. Proc. Natl. Acad. Sci. U.S.A., 55: 571 (1966).

23. Stormont, D., Davies, C., and Emmerson, B. T.: Urate production in heterozygotes for glucose-6-phosphotase deficiency. Clin. Chim. Acta, 71: 303 (1976).

24. Von Hoyningen-Huene, C. B. J.: Gout and glycogen storage disease in preadolescent brothers. Arch. Int. Med., 118: 471 (1966).

25. Yu, T. F., Sirota, J. H., Berger, L.: Effect of sodium lactate infusion on urate clearance in man. Proc. Soc. Exp. Biol. Med., 96: 809 (1957).

26. The diagnosis in this patient was made at the Vanderbilt Medical Center, Nashville, TN.

27. We thank D. Dittmar for assistance.

28. Scott Gold is a Summer Research Fellow, the National Foundation-March of Dimes.

29. This research was supported by a grant from the Hayward Foundation.

30. This study was conducted in the Clinical Research Unit of the University of Miami School of Medicine under a grant (RR-261) from the General Clinical Research Program of the Division of Research Resources, National Institutes of Health.

31. Requests for reprints should be addressed to: P. J. Benke, M.D., Mailman Center, University of Miami School of Medicine, Miami, FL 33152 (USA).

32. Received for publication March 7, 1977.

33. Accepted for publication June 16, 1977 